\title{
Energy and exergy analysis of air based photovoltaic thermal (PVT) collector: a review
}

\author{
Ahmad Fudholi ${ }^{1}$, Mariyam Fazleena Musthafa ${ }^{2}$, Abrar Ridwan ${ }^{3}$, Rado Yendra $^{4}$, Ari Pani Desvina ${ }^{5}$, \\ Rahmadeni $^{6}$, Tri Suyono ${ }^{7}$, Kamaruzzaman Sopian ${ }^{8}$ \\ ${ }^{1,2,8}$ Solar Energy Research Institute, Universiti Kebangsaan Malaysia, Malaysia \\ ${ }^{3}$ Program Study of Mechanical Engineering, Faculty of Engineering, Universitas Muhammadiyah Riau, Indonesia \\ ${ }^{4,5,6}$ Department of Mathematics, Faculty of Science and Technology, Universitas Islam Negeri Sultan Syarif Kasim \\ (UIN Suska), Indonesia \\ ${ }^{7}$ Universitas Khairun, Indonesia
}

\section{Article Info \\ Article history: \\ Received Jan 27, 2018 \\ Revised Jul 4, 2018 \\ Accepted Aug 11, 2018 \\ Keywords: \\ Electrical \\ Renewable energy \\ Thermal \\ Thermodynamics}

\begin{abstract}
Photovoltaic thermal (PVT) collectors convert solar radiation directly to both electrical and thermal energies. A PVT collector basiccaly combines the functions of a flat plate solar collector and those of a PV panel. This review presents thermodinamics fundamentals, descriptions, and previous works conducted on energy and exergy analysis of air based PVT collector. Studies in 2010 to 2018 of the energy and exergy analysis of air based PVT collectors are summarized. The energy and exergy efficiency of air based PVT collector ranges from $31 \%$ to $94 \%$ and $8.7 \%$ to $18 \%$, respectively. In addition, flat plate solar collector is presented. Studies conducted on air based PVT collectors are reviewed.
\end{abstract}

Copyright (C) 2019 Institute of Advanced Engineering and Science. All rights reserved.

\section{Corresponding Author:}

Ahmad Fudholi,

Solar Energy Research Institute, Universiti Kebangsaan Malaysia, 43600 Bangi Selangor, Malaysia.

Email: a.fudholi@gmail.com

\section{INTRODUCTION}

The depletion of conventional fossil fuels resources has revived the interest in renewable energy resource utilization. Therefore, an alternative energy source must determine to meet our energy requirements and for the preservation of conventional fossil fuels. Solar energy is one of the renewable energy sources and this clean energy has potential to meet a significant amount of the world's energy demand. The evolution of renewable energy sources such as solar energy is a source of energy that provides benefits to the environment and clean energy. Solar energy is also an alternative source to the poor or rural people who can not use modern energy sources. Thermal and electrical energy can be generated from solar energy. These two energies are produced in different forms but they can be produced simultaneously if hybrid collectors are used. This hybrid system is made up of a combination of two types of collectors, namely thermal collectors and photovoltaics in a unit called the photovoltaic-thermal (PVT) collector. PVT collector is a device designed to receive solar energy, convert it into thermal and electrical energy, which transfer the thermal energy to the fluid that flows into the collector. A PVT collector consisting of PV panel, insulation and frame. Accordingly, PVT collector consists of one or more cover (glass sheets) or a transparent material placed above an absorbing plate with air flowing around it. One way to enhance the collector's efficiency of PVT collector is use heat transfer area through absorber with finned absorber, corrugated surfaces, and porous media [1]-[8]. PVT collectpr can be classified into four types base on heat transfer medium; air-based 
PVT collector, water-based PVT collector, the combination of water/air-based PVT collector, and nanofluidbased PVT collector [9].

There are several advantages of PVT collectors over individual PV or thermal collectors discussed in various literature. According to Kumar \& Rosen [10], PVT systems produce 44\% more combined energy of useful thermal and electrical energy than individual systems with similar collector area. In addition, PVT system has economic advantages such as less payback time when operational in certain climatic conditions [10].

Kern \& Russel in 1978 introduced the concept of PVT collectors using air or water as a heat removal fluid. As such PVT collectors can be classified into three categories based on the type of working fluid used. Namely, water PVT collector, combination of water/air PVT collector and air PVT collector [11]. There are various types of Air based PVT collectors which has been designed, evaluated theoretically and experimentally by a number of researches. They are generally distinguished according to the air flow pattern based on whether the flow of air is above the absorber, below the absorber, on both sides of the absorber, in single and in double pass [12]. An unglazed air based PVT collector has $31.20 \%$ lower cost payback time compared to the standard PV system for 12 months [13] while the value for water based PVT collector is 28.1\% [14]. Recently, enviroeconomic and exergoeconomic analyses for air based PVT collectors was studied base on thermodynamics aspect [15], [16]. Thermodynamics is the study of heat, work, energy, and the changes they produce in the states of systems. In wider sense, thermodynamics examines the relationships between the macroscopic properties of a system. A system is in the state of thermodynamic equilibrium when no change in any microscopic properties takes place.

In this review, thermodynamic aspect is focused involving exergy analysis. Exergy analysis is conducted by utilizing the first and second law of thermodynamics. Exergy analysis has become an essential tool in the system design, analysis, and optimization of thermal systems [17]-[25].

\section{FLAT PLATE SOLAR COLLECTORS}

Flat plate solar collector is one of the most common type of solar thermal collector which is commonly used for low temperature applications. The design of the flat plate collector depends on the type of fluid used in the collector such as water or air. Flat plate water collector, as the name suggests, utilize water as a mean to extract heat. A simple flat plate water collector comprises of four main components: absorber plate, tubes fixed on the absorber plate, the transparent cover. Usually a low iron tempered glass is used as a transparent cover [26]. To increase the performance of the collector, the convective and radiative losses through the glass cover must be reduced and heat transfer from plate to the heat transfer fluid must be improved [27]. The key component of a solar water heater is the absorber plate which serves as the central module of a collector. It absorbs the maximum possible amount of solar irradiance and transfer the heat to the working fluid which is flowing in absorber tube [26]. Therefore, apart from the design of the absorber plate, the optical and thermal properties of the absorber play the most important roles on the performance of the solar collector. The material predominantly used as the absorber plate is copper or aluminum due to its effective thermal conductivity.

The useful energy gained from the collector is calculated using solar radiation magnitudes. The thermal efficiency of a solar collector is expressed as [28]-[30]:

$$
\eta_{t h}=\frac{Q}{A_{c} S}=\frac{m C\left(T_{o}-T_{i}\right)}{A_{c} S}
$$

where $\mathrm{Q}$ is the energy gained from the collector $(\mathrm{W}), \mathrm{m}$ is the mass flow rate $(\mathrm{kg} / \mathrm{s}), \mathrm{C}$ is the specific heat of air $\left(\mathrm{J} / \mathrm{kg}{ }^{\circ} \mathrm{C}\right), \mathrm{T}_{\mathrm{o}}$ is the outlet air temperature $\left({ }^{\circ} \mathrm{C}\right), \mathrm{T}_{\mathrm{i}}$ is the inlet air temperature $\left({ }^{\circ} \mathrm{C}\right), \mathrm{S}$ is the solar radiation $\left(\mathrm{W} / \mathrm{m}^{2}\right)$ and Ac is the collector area $\left(\mathrm{m}^{2}\right)$.

\section{THERMODYNAMICS FUNDAMENTALS OF AIR BASED PVT COLLECTORS}

First law of thermodinamics states that the energy balance of a certain system holds good when the system undergoes a change of state. But this law cannot provide any information on whether that change of state or process is feasible at all or not. For example, it cannot give information on whether a metallic bar of uniform temperature can spontaneously become warmer at one end and cooler at the other [31].

Second law of thermodynamics indicate the quality of the energy of the system [31]. According to Clausius' statement of the second law of thermodynamics, "it is impossible to construct a device which, operating in cycle, will produce no effect other than the transfer of heat from a cooler to a hotter body". Heat always flows from a body at a higher temperature to a body at a lower temperature. The reverse process can 
never occur without work being done [31]. It can also be stated in terms of entropy as "In any transfer or conversion of energy with in a closed system, the entropy of the system increases". The following statements can be derived using second law [32]: (i) the spontaneous or natural direction of energy transfer or conversion is toward increasing entropy, or (ii) all energy transfers or conversions are irreversible. Entropy is defined as the amount of molecular disorder with in a system [31]. Entropy increase and decrease during heat transfer in hot and cold bodies as show in the Figure 1.

In thermodynamics, the exergy of a system is the maximum useful work which is possible during a process that brings the system into the state of thermal equilibrium. It represents the maximum capacity of energy to perform useful work as the system proceeds to the equilibrium, with irreversibility increasing its entropy at the expense of exergy. Exergy is the difference between the total energy of the system and the unavailable energy (e.g. Losses) as shown in the Figure 2. A system in complete equilibrium with its environment has zero exergy [32].

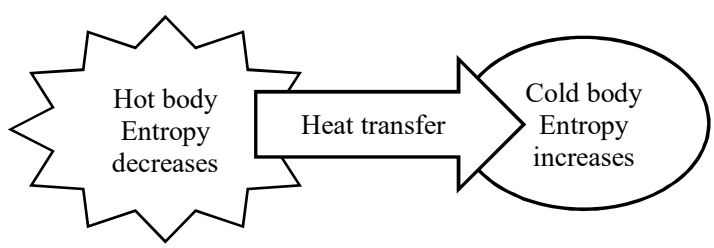

Figure 1. Entropy changes

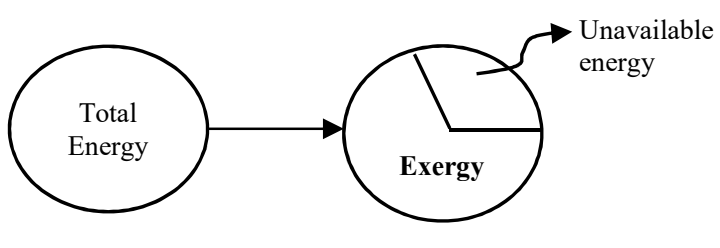

Figure 2. Demonstration of exergy

Exergy has the characteristic that it is conserved only when all processes of the system and the environment are reversible. Exergy is destroyed whenever an irreversible process occurs when an exergy analysis is performed on a system like PVT system, the thermodynamic imperfections can be quantified as exergy destruction, which is wasted work or wasted potential for the production of work. By analyzing the exergy destroyed by each component in a process, it can be easily identified where the focus should be given to improve system efficiency. Exergy analysis is conducted by utilizing the first and second law of thermodynamics.

Exergy analysis is a method that uses the conservation of the second law of thermodynamics for the analysis, design and improvement of energy (and other) systems. It is a useful method in achieving the goal of more efficient energy use as it enables us to determine the location, type and magnitude of wastes and losses. Exergy analysis can indicate whether or not and by how much a design of the energy system can be made efficient by reducing the inefficiencies in the system [33].

The performance of a PVT collector can be expressed as the combination of efficiency expressions consisting of thermal efficiency $\left(\eta_{\text {th }}\right)$ and electrical efficiency $\left(\eta_{\mathrm{PV}}\right)$. The overall performance of the system is evaluated using the total efficiencies, known as overall efficiency or PVT efficiency ( $\left.\eta_{\mathrm{PVT}}\right)$. It can be expressed as below [34]:

$$
\eta_{P V T}=\eta_{t h}+\eta_{P V}
$$

However, in order to evaluate the efficiency of the system more precisely, the exergy efficiency must be calculated using exergies for PV (electrical) and thermal. Assuming that the effects due to the kinetic and potential energy changes are insignificant, the general exergy balance can be expressed as following [35]:

$$
\sum E x_{i}-\sum E x_{o}=\sum E x_{d} \quad \text { or } \sum E x_{i}-\sum\left(E x_{t h}+E x_{P V}\right)=\sum E x_{d}
$$

where

$$
\begin{aligned}
& E x_{i}=A N S\left[1-\frac{4}{3}\left(\frac{T_{a}}{T_{s}}\right)+\frac{1}{3}\left(\frac{T_{a}}{T_{s}}\right)^{4}\right] \\
& E x_{t h}=m C\left(T_{o}-T_{i}\right)\left(1-\frac{T_{a}+273}{T_{o}+273}\right) \\
& E x_{P V}=\eta_{P V} A S \\
& \eta_{P V}=\eta_{0}\left[1-0.0045\left(T_{P V}-25\right)\right]
\end{aligned}
$$


The exergy efficiency is defined as the ratio of total exergy output to total exergy input and can be expressed as following [35]:

$$
\eta_{E x, P V T}=\frac{E x_{o}}{E x_{i}}
$$

\section{STUDIES CONDUCTED ON AIR BASED PVT COLLECTORS}

Hegazy [36] conducted an extensive investigation on overall performances analysis of flat plate air based PVT collectors. The investigation was based on the single glazing collectors, with air flowing over the absorber (Model I) or below it (Model II), and on both sides of the absorber in a single pass (Model III) or in a double pass (Model IV). Based on comparason, his analysis was concluded that for a given collector design, the temperature of the PV decreases due to increased flow rate, resulting in imrovement in electrical efficiency of the collector. Among the four PVT models, the overall performance was the lowest for model-I where the air was flowing over the absorber. Model III where air was flowing on both sides of the absorber in a single pass showed the highest overall performance followed by the Model IV where air was flowing on both sides of the absorber in a double pass. The flow channel ratio $\mathrm{D} / \mathrm{L}$ where $\mathrm{L}$ is the effective absorber area of length and $\mathrm{D}$ is the depth of the flow channel was found to be an important design parameter. For optimal thermo electric efficiency, the ratio must be equal to $2.5 \times 10-3$. The study also revealed that using of selective absorber plate in such types of PVT resulted in redcution in the electricity generation by PV. From the performance comparason, it was concluded that the Model III PVT collector is the most suitable design for converting solar energy into low quality heat and high quality electrical energy.

Tonui \& Tripanagnostopoulos [37] studied the effect of induced mass flow rate for both glazed and unglazed PVT prototype models. They concluded that the induced mass flow rate increases with increasing solar radiation due to more irradiance intercepted by the PVT collector. This resulted in increased heat energy transfer to the air flow in the channel which thereby increased the output temperature and creating higher stack effect.

Bambrook \& Sproul [38] conducted an experiment to maximise energy output of a PVT system in the Sydney climate. With increasing air mass flow rate, the thermal efficiency values increased, approaching a maximum value of around 55-60\%. However, while this thermal efficiency seem to be very good, at these higher air flow rates, the increase in the air temperature from the inlet to the outlet was found to be very small. The reason for outlet air temperature reduction with increasing air flow rate is when air flow velocity increases, air acquires less time inside the channel to attain higher outlet temperatures [39].

Tonui \& Tripanagnostopoulos [39] investigated and validated how air based PVT collectors heat extraction can be increased while keeping electrical efficiency at an acceptable level. It was found and verified that the energy efficiencies for finned, suspended metallic plate and normal air heaters respectively are $30 \%, 28 \%$ and $25 \%$. They also developed a similar model to validate the PV module temperature, back wall temperature and air outlet temperature of PVT configurations using thin flat metal sheet suspended at the middle or finned back wall of an air channel in the PVT. This model predicted the temperatures well enough to within an error of about $\pm 2^{\circ} \mathrm{C}$ on average for all measured temperatures. The effect of glazing was also analyzed by a number of researchers. According to the study conducted by Tonui \& Tripanagnostopoulos [39] a glazed air collector system has a higher thermal efficiency than the unglazed system due to the reduced heat losses however, it has lower electrical efficiency as a result of more absorption and reflection losses in the glass cover and higher PV module temperature. This also holds true for water cooled PVT [40].

Tripanagnostopoulos et al. [13] conducted an experiment to analyze the performance, cost and lifecycle assessment study of air based PVT collector system with glazed and unglazed collectors. Their result showed that by using thin fill metallic sheet (TFMS) modification in the air channel results in an increase of the combined electrical and thermal energy output compared to an unglazed air based PVT collector and higher electrical ouput than glazed PVT. Furthermore, the electrical output of the PVT was higher than the standard PV for only for the titled unglazed PVT and titled PVT with TFMS. The calculated thermal output for the heated air for 6 months is almost $40 \%$ of that from the reference mode of 12 months.

Many researchers have worked on the optimization of the solar air heater based on the exergy analysis. As such, Dubey et al. [41] conducted an exergy analysis on a PVT system with two configuration of air collectors. Joshi \& Tiwari [42] carried out the energy and exergy analysis of a PVT parallel plate air collector for the cold climate region of India (Srinagar). The analysis reported that the instantaneous energy and exergy efficiency of a Air based PVT collector ranges from 55-65\% and 12-15\%, respectively. Recently, Fudholi et al. [35] studied theoretical and experimental of air based PVT collector with $\nabla$-groove. They reported that PVT exergy efficiencies of were 12.66-12.91\% and PVT energy efficiencies were 
31.21-94.24\%. The thermal and PV efficiency was $21.3-82.9 \%$ and $9.87-11.34 \%$ respectively. Several studies on the energy and exergy analysis of air based PVT collectors were reported as shown in Table 1.

Tables 1. The Studies Conducted of Air Based PV/T Collectors

\begin{tabular}{|c|c|c|c|c|c|c|}
\hline \multirow{2}{*}{ Ref. } & \multirow{2}{*}{ Year } & \multirow{2}{*}{ Study } & \multicolumn{3}{|c|}{ Energy efficiency (\%) } & \multirow{2}{*}{$\begin{array}{c}\text { PVT } \\
\text { Exergy efficiency }\end{array}$} \\
\hline & & & PV & Thermal & PVT & \\
\hline$[35]$ & 2018 & Experimental and theoretical & $9.87-11.34$ & $21.3-82.9$ & $31.21-94.24$ & $12.66-12.91$ \\
\hline$[43]$ & 2016 & Experimental and theoretical & 15 & 50 & NA & 14.8 \\
\hline$[45]$ & 2016 & Experimental and theoretical & 10.5 & 70 & 90 & NA \\
\hline [46] & 2015 & Experimental & $3.1-9.1$ & $12.1-28.1$ & NA & NA \\
\hline [47] & 2015 & Experimental & 15 & 23 & 38 & NA \\
\hline [49] & 2015 & Experimental and theoretical & $11.9-12.4$ & 50 & 77.7 & NA \\
\hline$[50]$ & 2014 & Experimental & $8.3-10.4$ & $46-62$ & NA & NA \\
\hline$[51]$ & 2013 & Experimental and theoretical & NA & $\mathrm{NA}$ & NA & 16.3 \\
\hline$[52]$ & 2012 & Experimental and theoretical & 12.4 & 35.7 & NA & NA \\
\hline [53] & 2012 & Theoretical & $9-12.3$ & $19.4-22.8$ & $47.8-53.6$ & NA \\
\hline$[54]$ & 2010 & Experimental & 10 & 17.18 & 45 & 10.75 \\
\hline
\end{tabular}

\section{CONCLUSIONS}

Based on the present review, the following conclusions can be drawn: 1) A number of research have been done on air based PVT collectors over the last four decades, exploring aspects such as efficiency enhancements by design development, prototype design, simulation study, numerical study, testing methodologies and experimental testing for air based PVT collectors; 2) The energy and exergy efficiency of air based PVT collector ranges from $31 \%$ to $94 \%$ and $8.7 \%$ to $18 \%$, respectively. The variation of these efficiencies becaused different heat transfer area through absorber (finned absorber, corrugated surfaces, and porous media), design and air flow configuration (single-pass, double-pass, multy-pass, also with and without glass cover); 3) The development of air based PVT collectors is a very promising area of research. Today, air based PVT collectors using in solar drying and solar air heater.

\section{RECOMMENDATION AND FUTURE SCOPE}

The present review mainly focuses on the energy and exergy analyses of air based PVT collectors. The combination of energy-exergy-economic-environmental analyses was first applied to a solar collector by Caliskan [58]. As suggestion, researchers can be conducted environmental, enviroeconomic, exergoenvironmental, and exergoenviroeconomic analyses to analyze the performances of energy systems. The economic analyses of PVT collectors are limited in the literature. In addition, technoeconomic and thermoeconomic analyses are limited in the literature. Hence, further research on this topic can be conducted, and the results of these analyses can be applied for the improvement of PVT collectors or the energy system performance. The development of a hybrid PVT collector is a very promising area of research. Today, hybrid PVT collectors are utilized in various applications, such as solar drying, solar cooling, water heating, desalination, and pool heating. The future research trends about PVT collector for drying application is greenhouse dryer with hybrid PVT collector for industry scale. Further research is required to find new thermal storage materials and desiccant materials for this hybrid solar drying systems. Some of the recent developments in building integrated photovoltaic thermal (BIPVT) air collector, use of passive heat transfer augmentation methods, thermal storage with phase change material (PCM), nanofluids, use of heat pipes can be reviewed in future scope.

\section{ACKNOWLEDGEMENTS} 2017-045).

The authors would like to thank the UKM and UIN Suska Riau for funding (GP-K020448) and (GGP- 


\section{REFERENCES}

[1] N.S. Nazri, et al., "Energy Economic Analysis of Photo-Voltaic-Thermal-Thermoelectric (PVT-TE) Air Collectors," Renewable and Sustainable Energy Review, vol. 92, pp. 187-97, 2018.

[2] N.S. Nazri, et al., "Mathematical Modeling of Photovoltaic Thermal-Thermoelectric (PVT-TE) Air Collector," International Journal of Power Electronics and Drive Systems (IJPEDS), vol. 9, no. 2, pp. 795-802, 2018.

[3] A. Fudholi, et al., "Review on Exergy and Energy Analysis of Solar Air Heater" International Journal of Power Electronics and Drive Systems (IJPEDS), vol. 9, no. 1, pp. 420-26, 2018.

[4] A. Fudholi, et al., "Review on Solar Collector for Agricultural Produce," International Journal of Power Electronics and Drive Systems (IJPEDS), vol. 9, no. 1, pp. 414-19, 2018.

[5] A. Fudholi, et al., "Primary Study of Tracking Photovoltaic System for Mobile Station in Malaysia," International Journal of Power Electronics and Drive Systems (IJPEDS), vol. 9(1), pp. 427-32, 2018.

[6] C.N. Aisyah et al., "Kecekapan Pengumpul PV/T Menggunakan Pengumpul Terma Reka Bentuk Pilin (Efficiency of PV/T Collector Using Spiral Thermal Absorber Design)," Sains Malaysiana, vol. 47, no. 4, pp. 853-859, 2018.

[7] M. Zohri, et al., "Exergy Assessment of Photovoltaic Thermal with V-Groove Collector Using Theoretical Study. TELKOMNIKA (Telecommunication, Computing, Electronics and Control), vol. 16(2), pp. 550-57, 2018.

[8] M. Zohri, et al., "Photovoltaic Thermal (PVT) System with and Without Fins Collector: Theoretical Approach. International Journal of Power Electronics and Drive System (IJPEDS), vol. 8, no. 4, pp. 1756-63, 2017.

[9] A. Fudholi, et al., "R\&D of Photovoltaic Thermal (PVT) Systems: An Overview," International Journal of Power Electronics and Drive Systems (IJPEDS), vol. 9(2), pp. 803-10, 2018

[10] R. Kumar and M.A. Rosen, "A Critical Review of Photovoltaic-Thermal Solar Collectors for Air Heating," Applied Energy, vol. 88, no.11, pp. 3603-14, 2011.

[11] A. Ibrahim, et al., "Recent Advances In Flat Plate Photovoltaic/Thermal (PV/T) Solar Collectors," Renewable and Sustainable Energy Review, vol. 15, no.1, pp. 352-65, 2011.

[12] R.R. Avezov, et al., "A Review on Photovoltaicthermal (PV-T) Air and Water Collectors," Applied Solar Energy, vol. 47, no.3, pp. 169-183, 2011.

[13] Y. Tripanagnostopoulos, et al., "Performance, Cost and Life-Cycle Assessment Study of Hybrid PVT/AIR Solar Systems," Progress in Photovoltaics: Research and Applications, vol. 14, no.1, pp. 65-76, 2006.

[14] Y. Tripanagnostopoulos, et al., "Energy, Cost and LCA Results of PV and Hybrid PV/T Solar Systems," Progress in Photovoltaics: Research and Applications, vol. 13, no.3, pp. 235-50, 2005.

[15] Shyam \& G.N. Tiwari, "Analysis of Series Connected Photovoltaic Thermal Air Collectors Partially Covered by Semitransparent Photovoltaic Module," Solar Energy, vol. 137, pp. 452-62, 2016.

[16] C.S. Rajoria, et al., "A Newer Approach on Cash Flow Diagram to Investigate The Effect of Energy Payback Time and Earned Carbon Credits on Life Cycle Cost of Different Photovoltaic Thermal Array Systems," Solar Energy, vol. 124, pp. 254-67, 2016.

[17] A. Fudholi, et al., "Energy and Exergy Analyses of Solar Drying System for Red Seaweed," Energy and Buildings, vol. 68 , pp. 121-29, 2014.

[18] A. Fudholi, et al., "Performances and Improvement Potential of Solar Drying System for Palm Oil Fronds," Renewable Energy, vol. 78, pp. 561-65, 2015.

[19] A. Fudholi, et al., "Performance Analysis of Solar Drying System for Red Chili," Solar Energy, vol. 99, pp. 47-54, 2014.

[20] A. Fudholi, et al., "Energy Analysis and Improvement Potential of Finned Double-Pass Solar Collector," Energy Conversion and Management, vol. 75, pp. 234-40, 2013.

[21] A. Fudholi, et al., "Review of Solar Drying Systems with Air-Based Solar Collectors in Malaysia," Renewable and Sustainable Energy Review, vol. 51, pp. 1191-1204, 2015.

[22] A. Fudholi, et al., "Techno-economic of Solar Drying Systems with Water Based Solar Collectors in Malaysia: A Review," Renewable and Sustainable Energy Review, vol. 51, pp. 809-820, 2015.

[23] M. Yahya, et al., "Energy and Exergy Analyses of Solar-Assisted Fluidized Bed Drying Integrated With Biomass Furnace," Renewable Energy, vol. 105, pp. 22-29, 2017.

[24] S.A. Kalogirou, et al., "Exergy Analysis on Solar Thermal Systems: A Better Understanding of Their Sustainability," Renewable Energy, vol. 85, pp. 1328-33, 2016.

[25] A. Ibrahim, et al., "Efficiencies and Improvement Potential of Building Integrated Photovoltaic Thermal (BIPVT) System," Energy Conversion and Management, vol. 77, pp. 527-34, 2014.

[26] D.D. Chincholkar and P.R. Kulkarni, "Performance Improvement of Solar Flat Plate Collector Using Formed Tubes-A Review," International Journal of Advance Engineering Technology, vol. 6, no.2, pp. 32-33, 2015.

[27] A.M. Shariah, et al., "Effect of Thermal Conductivity of Absorber Plate On The Performance of a Solar Water Heater," Applied Thermal Engineering, vol. 19, pp. 733-41, 1999.

[28] A. Fudholi, et al., "Performance and Cost Benefits Analysis of Double-Pass Solar Collector with and Without Fins," Energy Conversion and Management, vol. 76, pp. 8-19, 2013.

[29] A. Fudholi, et al., "Collector Efficiency of the Double-Pass Solar Air Collectors with Fins," Proceedings of the 9th WSEAS International Conference on SYSTEM SCIENCE and SIMULATION in ENGINEERING (ICOSSSE'10), Japan, 2010, pp. 428-34.

[30] A. Fudholi, et al., "Experimental Study of the Double-Pass Solar Air Collector with Staggered Fins," Proceedings of the 9th WSEAS International Conference on System Science and Simulation in Engineering (ICOSSSE'10), Japan, 2010, pp. 410-14.

[31] P. Nag, "Basic and Applied Thermodynamics," New Delhi, India: Tata McGrawHill, 2002. 
[32] T. Tadese and G. Tesema, " Energy, Entropy and Exergy Concepts: Thermodynamic Approach, A Critical Review," Abhinav National Monthly Refereed Journal of Research in Science \& Technology, vol. 3, no.5, 2014.

[33] M. Rosen and I. Dincer, "Exergy as The Confluence of Energy, Environment and Sustainable Development," Exergy, An International Journal, vol. 1, no.1, pp. 3-13, 2001.

[34] A. Fudholi, et al., "Performance Analysis of Photovoltaic Thermal (PVT) Water Collectors," Energy Conversion and Management, vol. 78, pp. 641-651, 2014.

[35] A. Fudholi, et al., "Energy and Exergy Analyses of Photovoltaic Thermal Collector with $\nabla$-groove," Solar Energy, vol. 159, pp. 742-50, 2018.

[36] A. Hegazy, et al., "Comparative Study Of the Performances of Four Photovoltaic/Thermal Solar Air Collectors," Energy Conversion and Management, vol. 41, pp. 861-81, 2000.

[37] J.K. Tonui and Y. Tripanagnostopoulos, "Performance Improvement of PV/T Solar Collectors with Natural Air Flow Operation," Solar Energy, vol. 82, no.1, pp. 1-12, 2008.

[38] S.M. Bambrook and Sproul, "Maximising the Energy Output of a PVT Air System," Solar Energy, vol. 86, no.6, pp. 1857-71, 2012.

[39] J.K. Tonui and Y. Tripanagnostopoulos, "Air-cooled PV/T Solar Collectors with Low Cost Performance Improvements," Solar Energy, vol. 81, no.4, pp. 498-511, 2007.

[40] P.G. Charalambous, et al., "Photovoltaic Thermal (PV/T) Collectors: A Review," Applied Thermal Engineering, vol. 27, no.2-3, pp. 275-86, 2007.

[41] S. Dubey, et al., "Energy and exergy analysis of PV/T air collectors connected in series," Energy and Buildings, vol. 41, no.8, pp. 863-70, 2009.

[42] A.S. Joshi and A. Tiwari, "Energy and Exergy Efficiencies of a Hybrid Photovoltaic-Thermal (PV/T) Air Collector," Renewable Energy, vol. 32, no.13, pp. 2223-41, 2007.

[43] M. Hazami, et al., "Energetic and Exergetic Performances Analysis of a PV/T (Photovoltaic Thermal) Solar System Tested and Simulated Under to Tunisian (North Africa) Climatic Conditions," Energy, vol. 107, pp. 78-94, 2016.

[44] M.E.A.Slimani, et al., "Study and Modeling of Energy Performance of A Hybrid Photovoltaic/Thermal Solar Collector: Configuration Suitable For an Indirect Solar Dryer," Energy Conversion and Management, vol. 125, pp. 209-21, 2016.

[45] M. Gholampour \& M. Ameri, "Energy and Exergy Analyses of Photovoltaic/Thermal Flat Transpired Collectors: Experimental and Theoretical Study," Applied Energy, vol. 164, pp. 837-56, 2016.

[46] Y. Li, et al., "Performance Study of a Solar Photovoltaic Air Conditioner in the Hot Summer and Cold Winter Zone," Solar Energy, vol. 117, pp. 167-79, 2015.

[47] C.S. Rajoria, et al., "Exergetic and Enviroeconomic Analysis of Semitransparent PVT Array based on Optimum Air Flow Configuration and Its Comparative Study," Solar Energy, vol. 122, pp. 1138-45, 2015.

[48] J.G. Ahn, et al., "A Study on Experimental Performance of Air-Type PV/T Collector with HRV," Energy Procedia, vol. 78, pp. 3007-12, 2015.

[49] C. Good, et al., "Solar Energy for Net Zero Energy Buildings-A Comparison between Solar Thermal, PV and Photovoltaic-Thermal (PV/T) Systems," Solar Energy, vol. 122, pp. 986-96, 2015.

[50] K.E. Amori, M.A. Abd-AlRaheem, "Field Study of Various Air based Photovoltaic/Thermal Hybrid Solar Collectors," Renewable Energy, vol. 63, pp. 402-14, 2014

[51] C.S. Rajoria, et al., "Exergetic and Enviroeconomic Analysis of Novel Hybrid PVT Array," Solar Energy, vol. 88, pp. 110-19, 2013.

[52] S. Agrawal, et al., "Indoor Experimental Analysis of Glazed Hybrid Photovoltaic Thermal Tiles Air Collector Connected in Series," Energy and Buildings, vol. 53, pp. 145-51, 2012.

[53] K.E. Amori, and H.M.T. Al-Najjar," Analysis of Thermal and Electrical Performance of a Hybrid (PV/T) Air Based Solar Collector for Iraq," Applied Energy, vol. 98, pp. 384-95, 2012.

[54] B. Agrawal \& G.N. Tiwari, "Optimizing the Energy and Exergy of Building Integrated Photovoltaic Thermal (BIPVT) Systems Under Cold Climatic Conditions," Applied Energy, vol. 87, pp. 417-26, 2010.

[55] F. Sarhaddi, et al., "Exergetic Performance Assessment of a Solar Photovoltaic Thermal (PV/T) Air Collector," Energy and Buildings, vol. 42, pp. 2184-99, 2010.

[56] F. Sarhaddi, et al., "An Improved Thermal and Electrical Model for a Solar Photovoltaic Thermal (PV/T) Air Collector," Applied Energy, vol. 87, pp. 2328-39, 2010.

[57] B. Agrawal \& G.N. Tiwari, "Life cycle cost assessment of building integrated photovoltaic thermal (BIPVT) systems," Energy and Buildings, vol. 42, pp. 1472-81, 2010.

[58] H. Caliskan, "Energy, Exergy, Environmental, Enviroeconomic, Exergoenvironmental (EXEN) and Exergoenviroeconomic (EXENNEC) Analyses of Solar Collectors," Renewable and Sustainable Energy Review, vol. 69, pp. 488-492, 2017. 


\section{BIOGRAPHIES OF AUTHORS}

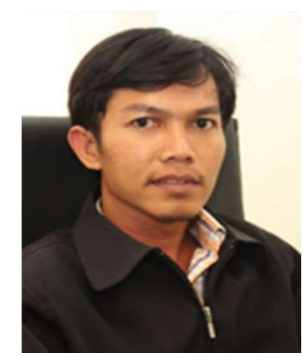

Ahmad Fudholi, Ph.D, M.Sc obtained his S.Si (2002) in physics. He was born in 1980 in Pekanbaru, Indonesia. He has working experience about 4 years (2004-2008) as Head of Physics Department at Rab University Pekanbaru, Riau, Indonesia. A. Fudholi started his master course in Energy Technology (2005-2007) at Universiti Kebangsaan Malaysia (UKM). His M.Sc thesis was on Wind/PV Hybrid System and the Ph.D thesis was about the Finned Double-Pass Solar Collectors for Drying of Seaweed. His M.Sc and Ph.D thesis under supervisor by Prof Dato' Dr. Kamaruzzaman Sopian. After his master he became Research Assistant at UKM up to 2012. After his Ph.D (2012) in renewable energy, he became Postdoctoral in Solar Energy Research Institute (SERI) UKM up to 2013. He joined the SERI as a Lecture in 2014. More than USD 310,000 research grant (15 grant/ project) in 2014-2017 was involved. More than $25 \mathrm{M}$.Sc project supervised and completed. Until now, he managed to supervise $5 \mathrm{Ph} . \mathrm{D}$ (4 main supervisors and $1 \mathrm{Co}$. supervisor), 3 Master's student by research mode, and 5 Master's student by coursework mode, he was also as examiner ( $3 \mathrm{Ph} . \mathrm{D}$ and $1 \mathrm{M} . \mathrm{Sc})$. His current research focuses on renewable energy, especially solar energy technology, micropower system, solar drying systems, and advanced solar thermal systems (solar assisted drying, solar heat pump, PVT systems). He has published more than 120 peer-reviewed papers, which 25 papers in ISI index (20 Q1, impact factor more than 3) and more than 60 papers in Scopus index, 16 more currently accepted manuscript, 20 more currently under review, and 2 book chapters. Addition, he has published more than 70 papers in international conferences. His total citations of 810 and hindex of 14 in Scopus (Author ID: 57195432490). His total citations of 1387 and h-index of 20 in google scholar. He is appointed as reviewer of high impact (Q1) journal such as Renewable and Sustainable Energy Reviews, Energy Conversion and Management, Applied Energy, Energy and Buildings, Applied Thermal Engineering, Energy, Industrial Crops and Products, etc. He is appointed as reviewer of reputation journals such as Drying Technology, International Journal of Green Energy, Biosystem Engineering, Journal of Sustainability Science and Management, Journal of Energy Efficiency, Sains Malaysiana, Jurnal Teknologi etc. He is also appointed as editor journals. He has received several awards such as Gold Medal Award at the International Ibn Al-Haytham's Al-Manazir Innovation and Invention Exhibition 2011, Silver Medal Award at the International Technology EXPO (ITEX) 2012, Silver Medal Award at the Malaysia Technology Expo (MTE) 2013, Bronze Medal Award at International Exposition of Research and Invention (PECIPTA) 2011, also 2 Bronze Medal Award at PECIPTA 2017. He was also invited as speaker: Workshop of Scientific Journal Writing; Writing Scientific Papers Steps Towards Successful Publish in High Impact (Q1) Journals. He has 1 patent and 2 copyrights.

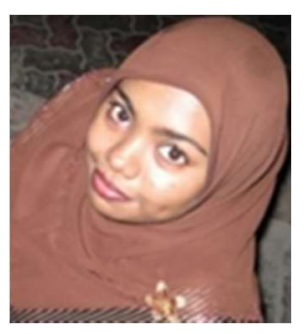

Mariyam Fazleena Musthafa, M.Sc from Maldives. She graduated with the M.Sc (2017) in Energy Technology from Universiti Kebangsaan Malaysia (UKM), Malaysia. The M.Sc dissertation was about the Exergy Analysis of Photovoltaic Thermal (PVT) Air Collector. Her M.Sc thesis under supervisor by Ahmad Fudholi, Ph.D. Upon graduation her current research focuses on solar energy technology.

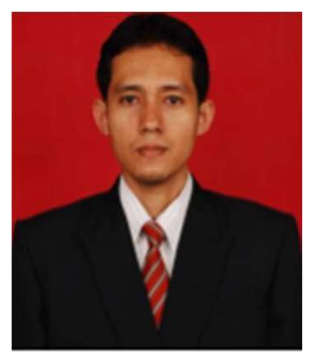

Abrar Ridwan, S.Si, ST, MT is the head of centre of applied technology, head of mechanical engineering laboratory and a lecturer at Muhammadiyah University of Riau. His research interest includes combustion engineering, biomass gasification, energy conversion and solar energy. He was graduated from physic department of Brawijaya university and also in mechanical engineering at Muhammadiyah University of Malang (UMM). Since 8 years of his lecture was granted by Research and Technology Ministries of Indonesia (RistekDikti) for his research project. He is also involved in the UNDP-UNFCC program regarding municipal solid waste project in Riau Province and graduated his master of mechanical engineering from University of Indonesia. Currently he is focusing the research of how to optimize solar updraft power generator with any material as its heat storage. 


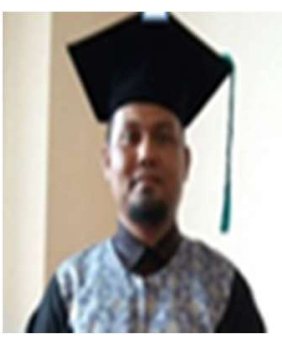

Dr. Rado Yendra, M.Sc was born in Indonesia in 1977. He received Ph.D. degree in Statistical Science from The National University of Malaysia, Malaysia in 2014. He joined the Department of Mathematics from the State Islamic University of Sultan Syarif Kasim Riau, Indonesia and 2015 became a Vice-Dean from Faculty of Science and Technology. His main areas of research interest are statistical science and data mining.



Ari Pani Desvina, S.Si, M.Sc from Indonesia. She graduated with the M.Sc in Statistical Science from The National University of Malaysia, Malaysia in 2010. She joined as lecturer at the Department of Mathematics, Faculty of Science and Technology, Universitas Islam Negeri Sultan Syarif Kasim (UIN Suska) in 2006. Carenntly, she is head of Mathematics Department of UIN Suska Riau, Indonesia.

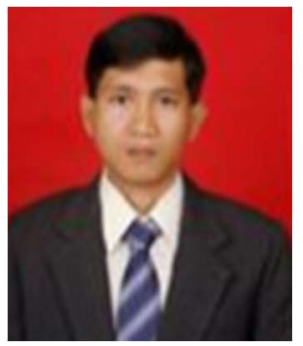

Tri Suyono, ST, M.Sc.,REN graduated with the M.Sc REN in Renewable Energy from Solar Energy Research Institute (SERI), UKM, Malaysia. The M.Sc thesis was about the Design and Performance of Solar Assisted Drying System with Solid Desiccant Wheel. He received "SUBROTO Award in Energy Inovation Field" from Minister of Energy and Mineral Resources Republic of Indonesia in 2017. He has working as Lecturer at Universitas Khairun, Indonesia since 2004. He has working experience more than 10 year as Consultant and Contractor in Marine Technology, Renewable Energy, Water Supply Systems Engineering, Subsea Pipeline Engineering, Energy Coversion, Drying Technology and Air Conditioning Systems.



Prof Dato' Dr. Kamaruzzaman Sopian graduated with the BS Mechanical Engineering from the University of Wisconsin-Madison in 1985, the MS in Energy Resources University of Pittsburgh in 1989 and $\mathrm{PhD}$ in Mechanical Engineering from the Dorgan Solar Laboratory, University of Miami at Coral Gables in 1997. He has been involved in the field of renewable energy for more than 25-years. He has secure research funding from the Malaysian Minstry of Science and Malaysian Ministry of Education and industry for more than USD 6 million. He has conducted renewable enery courses the Asian School of Energy (2007-2014) funded by ISESCO, COMSAT, TIKA and UNESCO. He has published over 800 research papers in journals and conferences (SCOPUS h index $=53$, no. of citation $=9386)($ Google Scholar $\mathrm{h}$ index $=64$, no. of citation $=15531$ ). A total of $32 \mathrm{MSc}$ (coursework), $15 \mathrm{MSc}$ (research mode) and $40 \mathrm{PhD}$ supervised and completed. 